\title{
Is Indenyl a Stronger or Weaker Electron Donor Ligand than Cyclopentadienyl? Opposing Effects of Indenyl Electron Density and Ring Slipping on Electrochemical Potentials
}

\author{
Khiem T. Nguyen, Emily E. Lane, Colin D. McMillen, Jared A. Pienkos, and Paul S. Wagenknecht*
}

Cite This: Organometallics 2020, 39, 670-678

Read Online

ABSTRACT: Complexes of the type ${ }^{\mathrm{R}} \mathrm{Cp}_{2} \mathrm{Ti}\left(\mathrm{C}_{2} \mathrm{Fc}\right)_{2}$ (where ${ }^{\mathrm{R}} \mathrm{Cp}=$ cyclopentadienyl or a substituted cyclopentadienyl) have high molar absorptivity $\mathrm{Fe}^{\mathrm{II}}$ to $\mathrm{Ti}^{\mathrm{IV}}$ metal-to-metal charge transfer (MMCT) absorptions and have been investigated for possible use as photoredox catalysts. Relative to $\mathrm{Cp}_{2} \mathrm{Ti}\left(\mathrm{C}_{2} \mathrm{Fc}\right)_{2}$, the MMCT shifts to higher or lower energy when ${ }^{\mathrm{R}} \mathrm{Cp}$ is either a stronger or weaker donor ligand than $\mathrm{Cp}$, respectively. The indenyl ligand (Ind) has been described in the literature as both a stronger and weaker donor ligand than $\mathrm{Cp}$. Herein, we report the preparation of $\operatorname{Ind}_{2} \mathrm{Ti}\left(\mathrm{C}_{2} \mathrm{Fc}\right)_{2}$ and the complex with $\mathrm{CuBr}$ bound between the two alkynes, $\operatorname{Ind}_{2} \mathrm{Ti}\left(\mathrm{C}_{2} \mathrm{Fc}\right)_{2} \mathrm{CuBr}$, in order to determine the effect that replacing $\mathrm{Cp}$ with Ind has on the MMCT

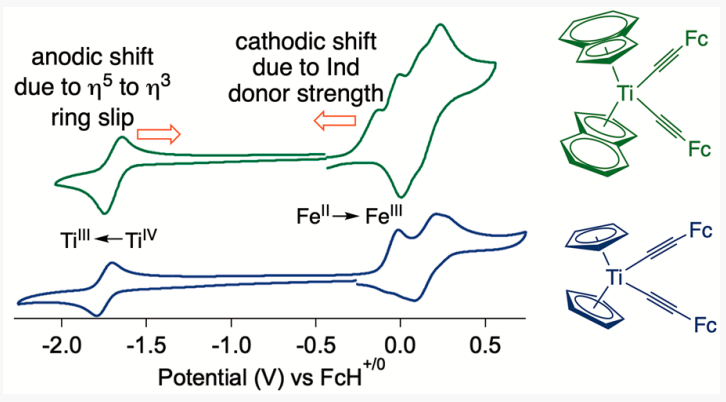
absorption energy. The complexes are characterized by NMR and UVvis spectroscopy, cyclic voltammetry, and X-ray crystallography in the case of $\operatorname{Ind}_{2} \mathrm{Ti}_{(}\left(\mathrm{C}_{2} \mathrm{Fc}\right)_{2} \mathrm{CuBr}$. Relative to $\mathrm{Cp}_{2} \mathrm{Ti}\left(\mathrm{C}_{2} \mathrm{Fc}\right)_{2}$, the $\mathrm{Fe}^{\mathrm{III} / \mathrm{II}}$ potential of $\mathrm{Ind}_{2} \mathrm{Ti}\left(\mathrm{C}_{2} \mathrm{Fc}\right)_{2}$ shifts cathodically and the $\mathrm{Ti}^{\mathrm{iV} / \mathrm{III}}$ potential shifts anodically, resulting in a lower energy MMCT absorption. The $\mathrm{Ti}^{\mathrm{IV} / \mathrm{III}}$ reduction wave is also chemically irreversible, with $i_{\mathrm{pa}} / i_{\mathrm{pc}}$ approaching unity as the scan rate is increased from 10 to $500 \mathrm{mV} / \mathrm{s}$. Examination of the literature reviewed in this report demonstrates that, in all cases, replacement of Cp with Ind leads to a cathodic shift of the potential for metal oxidation. However, replacement of $\mathrm{Cp}$ with Ind typically leads to an anodic shift of the reduction potential, leading some to suggest that Ind is a poorer $\mathrm{e}^{-}$donor than $\mathrm{Cp}$. In the context of the literature, these results are interpreted as indicating that Ind is a better electron donor than $\mathrm{Cp}$, but that reduction induces an $\eta^{5}$ to $\eta^{3}$ haptotropic shift that is rapid on the electrochemical time scale, stabilizing the reduction product, resulting in an anodic shift of the $\mathrm{Ti}{ }^{\mathrm{IV} / \mathrm{III}}$ reduction. Furthermore, these opposing effects are not unique to this system.

\section{INTRODUCTION}

Since the initial discovery of ferrocene nearly 70 years ago, ${ }^{1,2}$ organometallic complexes with cyclopentadienyl (Cp) ligands have been among the most extensively investigated and applied molecules in the realm of organometallic structure and reactivity. Though less investigated, indenyl (Ind) complexes often show improved catalytic activity relative to their cyclopentadienyl complex analogues. ${ }^{3}$ The improved catalytic behavior is often related to the increased rate of substitution chemistry for indenyl metal complexes. This "indenyl effect" was first reported in 1969 for a migratory insertion reaction where (Ind) $\mathrm{Mo}(\mathrm{CO})_{3} \mathrm{CH}_{3}$ reacts with $\mathrm{PPh}_{3}$ to give (Ind)Mo(CO) $)_{2} \mathrm{PPh}_{3} \mathrm{COCH}_{3}$. ${ }^{4}$ The rate acceleration with respect to the $\mathrm{Cp}$ complex was suggested to be the result of a more favorable $\eta^{5}$ to $\eta^{3}$ ring slip for the indenyl complexes compared to the cyclopentadienyl complexes (Figure 1). Such a ring slip decreases the electron count at the central metal, thus lowering the energy barrier for coordination of the additional ligand necessary to induce the migratory insertion. ${ }^{4,5}$ Since that initial discovery, the indenyl effect has been shown to be a quite general phenomenon for indenyl complexes. ${ }^{5-7}$ The gener-

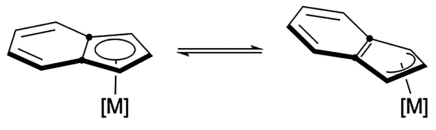

Figure 1. $\eta^{5}$ to $\eta^{3}$ haptotropic shift.

ation of aromaticity in the fused benzo ring has typically been cited for the increased ability of indenyl to undergo $\eta^{5}$ to $\eta^{3}$ ring slip, ${ }^{4-6}$ but more recent computational studies suggest that the indenyl effect is related to the relative metal $\pi$-ligand bond strengths for $\mathrm{Cp}$ and Ind in each binding mode.

This differential behavior of the $\mathrm{Cp}$ and Ind complexes has stimulated investigations into the relative electronic nature of these two ligands. Several investigations suggest that the Ind ligand is more electron-rich than the $\mathrm{Cp}$ ligand, whereas others

Received: December 2, 2019

Published: January 23, 2020 
suggest Ind is more electron-poor. For example, photoelectron spectroscopy on $\mathrm{d}^{6}$ and $\mathrm{d}^{8}$ complexes has suggested that for such complexes, the Ind ligand is more electron-rich than the Cp ligand. ${ }^{8,9}$ This is consistent with what is observed in infrared spectroscopic investigations ${ }^{10}$ and redox potentials for metal oxidation in $\mathrm{d}^{6}$ complexes. ${ }^{6,11}$ This contrasts with what reduction potentials of $\eta^{5}$-Ind complexes suggest, where replacement of $\mathrm{Cp}$ with Ind typically results in an anodic shift of the metal-centered reduction, ${ }^{12-14}$ leading some authors to suggest that Ind is a poorer donor compared to Cp. ${ }^{14}$

Recently, we have been interested in complexes of the type ${ }^{\mathrm{R}} \mathrm{Cp}_{2} \mathrm{Ti}\left(\mathrm{C}_{2} \mathrm{Fc}\right)_{2}$ (Figure 2) which show an intense electronic
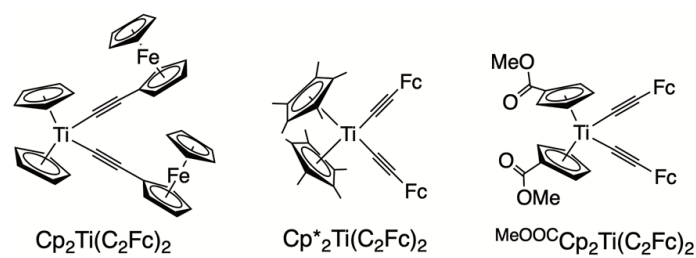

$\mathrm{Cp}_{2} \mathrm{Ti}\left(\mathrm{C}_{2} \mathrm{Fc}\right)_{2}$

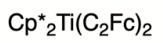

${ }^{\mathrm{MeOOC}} \mathrm{Cp}_{2} \mathrm{Ti}\left(\mathrm{C}_{2} \mathrm{Fc}\right)_{2}$
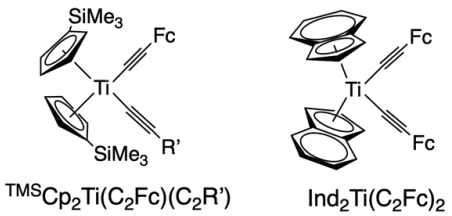

Figure 2. $\mathrm{Fe}^{\mathrm{II}}-\mathrm{Ti}^{\mathrm{IV}}$ complexes discussed in this paper along with abbreviations used. ${ }^{\mathrm{R}} \mathrm{Cp}_{2} \mathrm{Ti}\left(\mathrm{C}_{2} \mathrm{Fc}\right)_{2}$ is the general abbreviation used to refer to the complexes with two ethynylferrocene ligands and any substitution on the $\mathrm{Cp}$ ring (top row).

$\mathrm{Fe}^{\mathrm{II}}$ to $\mathrm{Ti}^{\mathrm{IV}}$ metal-to-metal charge-transfer (MMCT) absorption. ${ }^{15-17}$ The excited state ${ }^{\mathrm{R}} \mathrm{Cp}_{2} \mathrm{Ti}\left(\mathrm{C}_{2} \mathrm{Fc}\right)_{2}{ }^{+/ 0}$ potential is estimated to be more negative than $-1.30 \mathrm{~V}$ vs $\mathrm{FcH}^{+/ 0}$, suggesting that these complexes may be potent excited state reducing agents. ${ }^{15}$ Moreover, the energy of the CT band can be tuned by the nature of the substituents on the $\mathrm{Cp}$ ligands. For example, when ${ }^{\mathrm{R}} \mathrm{Cp}$ is pentamethylcyclopentadienyl $\left(\mathrm{Cp}^{*}\right)$, there is a cathodic shift of the $\mathrm{Ti}^{\mathrm{IV} / \mathrm{III}}$ reduction potential relative to that of the corresponding $\mathrm{Cp}$ complex and a concomitant blue-shift of the $\mathrm{Fe}^{\mathrm{II}}$ to $\mathrm{Ti}^{\mathrm{IV}}$ MMCT. ${ }^{15}$ On the other hand, when ${ }^{\mathrm{R}} \mathrm{Cp}$ is a methyl ester substituted cyclopentadienyl $\left({ }^{\mathrm{MeOOC}} \mathrm{Cp}\right.$ ), the $\mathrm{Ti}^{\mathrm{IV} / \mathrm{III}}$ reduction potential shifts anodically relative to the $\mathrm{Cp}$ complex, resulting in a redshift of the $\mathrm{Fe}^{\mathrm{II}}$ to $\mathrm{Ti}^{\mathrm{IV}} \mathrm{MMCT}$ (Figure 3). ${ }^{17}$ Given the inconsistent statements in the literature regarding the donor properties of Ind vs $\mathrm{Cp}$, we set out to investigate the corresponding $\operatorname{Ind}_{2} \mathrm{Ti}\left(\mathrm{C}_{2} \mathrm{Fc}\right)_{2}$ complex (Figure 2), partly out of curiosity regarding whether the $\mathrm{Fe}^{\mathrm{II}}$ to $\mathrm{Ti}^{\mathrm{IV}} \mathrm{MMCT}$ would redshift or blue-shift relative to its $\mathrm{Cp}$ analogue.

Herein, we report the synthesis and characterization of $\operatorname{Ind}_{2} \mathrm{Ti}\left(\mathrm{C}_{2} \mathrm{Fc}\right)_{2}$, and a derivative where $\mathrm{CuBr}$ is bound between the alkynes. We focus on seemingly incompatible findings regarding the electrochemistry of $\operatorname{Ind}_{2} \mathrm{Ti}\left(\mathrm{C}_{2} \mathrm{Fc}\right)_{2}$. Chiefly, the $\mathrm{Fc}^{+/ 0}$ potential for the bound ethynylferrocene ligand shifts cathodically relative to the corresponding $\mathrm{Cp}$ complex, consistent with Ind being more electron-rich and there being an inductive effect through to the Fc. However, there is a corresponding slight anodic shift of the $\mathrm{Ti}^{\mathrm{IV} / \mathrm{III}}$ reduction potential, consistent with what is typically observed for metalcentered reductions upon replacement of $\mathrm{Cp}$ with Ind, but

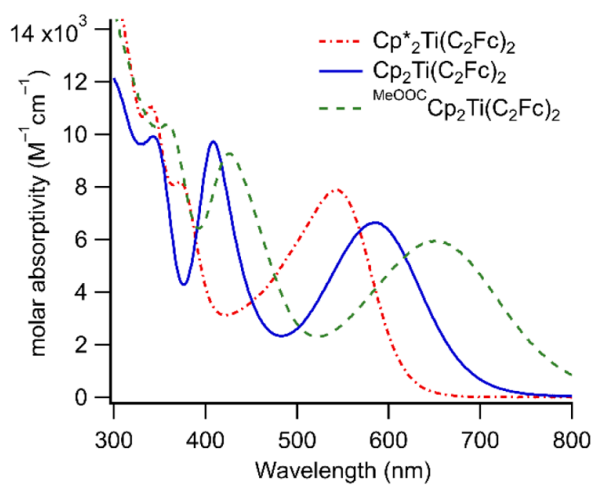

Figure 3. UV-vis absorption spectra in $\mathrm{CH}_{2} \mathrm{Cl}_{2}$ for the ${ }^{\mathrm{R}} \mathrm{Cp}_{2} \mathrm{Ti}$ $\left(\mathrm{C}_{2} \mathrm{Fc}\right)_{2}$ complexes. The color of the curves approximates the color of each complex.

inconsistent with Ind being more electron-rich than $\mathrm{Cp}$. The observation that Ind shifts the oxidation of $\mathrm{Fe}^{\mathrm{II}}$ in the cathodic direction and the reduction of $\mathrm{Ti}^{\mathrm{IV}}$ in the anodic direction, all within the same molecule, suggests that this might be a general phenomenon, rather than the direction of the shift being dependent on the electronic properties of the metal on which the $\mathrm{Cp} /$ Ind substitution is implemented. This phenomenon is explored along with the impact of these electrochemical potentials on the energy of the MMCT transition in this complex.

\section{RESULTS}

Synthesis and General Characterization. The complexes investigated herein were prepared according to the literature procedures for the analogous complexes with $\mathrm{Cp}$ ligands (Figure 4). ${ }^{15,16}$ The syntheses were performed under

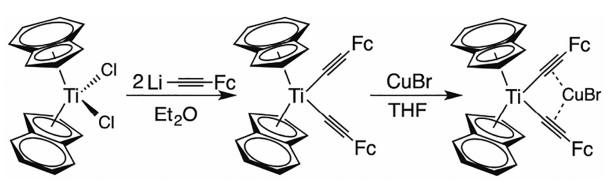

Figure 4. General synthetic scheme for the complexes reported herein.

Ar in anhydrous conditions, but the products are stable to atmospheric conditions and are also photostable. Thus, all purifications and subsequent manipulations were performed on the benchtop without the need for inert atmosphere or anhydrous solvent. Like the corresponding $\mathrm{Cp}$ complexes, the Ind complexes are sensitive to acid hydrolysis. Thus, $\mathrm{CDCl}_{3}$ for NMR spectroscopy is passed through activated alumina to remove any acidic impurities. In $\mathrm{CDCl}_{3}$, the indenyl hydrogens of $\operatorname{Ind}_{2} \mathrm{Ti}\left(\mathrm{C}_{2} \mathrm{Fc}\right)_{2}$ are overlapping, but these are well resolved in $\mathrm{C}_{6} \mathrm{D}_{6}$ (Supporting Information, Figure $\mathrm{S} 1$ ). The ferrocenyl hydrogens appear as a singlet at $4.20 \mathrm{ppm}$ for the unsubstituted $\mathrm{Cp}$ ring and two apparent triplets $\left(\mathrm{dd}, J_{1}=J_{2}\right)$ at 4.00 and 4.40 $\mathrm{ppm}$ for the substituted $\mathrm{Cp}$ ring. The indenyl hydrogens on the $\mathrm{C}_{5}$ ring appear as a doublet at $6.17 \mathrm{ppm}$ and a triplet at 6.20 $\mathrm{ppm}$, and those on the $\mathrm{C}_{6}$ ring as two doublets of doublets at 7.00 and $7.51 \mathrm{ppm}$.

Coordination of $\mathrm{CuBr}$ occurs between the alkynyl ligands as has been previously reported for bis-alkynyl titanocenes. ${ }^{16,18-20}$ Diagnostic of this coordination is a shift of 
$\nu_{\mathrm{C} \equiv \mathrm{C}}$ from $2048 \mathrm{~cm}^{-1}$ for the parent $\operatorname{Ind}_{2} \mathrm{Ti}\left(\mathrm{C}_{2} \mathrm{Fc}\right)_{2}$ to 1986 $\mathrm{cm}^{-1}$ for $\operatorname{Ind}_{2} \mathrm{Ti}\left(\mathrm{C}_{2} \mathrm{Fc}\right)_{2} \mathrm{CuBr}$, in agreement with previous examples where $\mathrm{Cu}^{\mathrm{I}}$ was coordinated between the alkynes. ${ }^{16,18-20}$ This structure was confirmed using X-ray crystallography (Figure 5, and Supporting Information Table

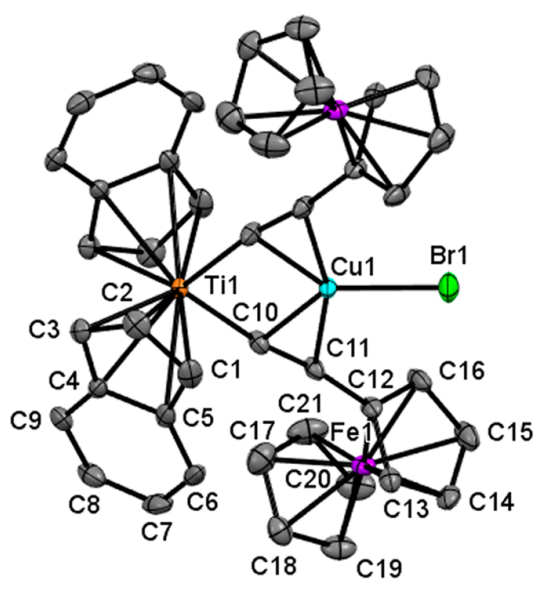

Figure 5. Structure of $\operatorname{Ind}_{2} \mathrm{Ti}\left(\mathrm{C}_{2} \mathrm{Fc}\right)_{2} \mathrm{CuBr}$ shown as $50 \%$ probability ellipsoids. Hydrogen atoms omitted for clarity. Key interatomic distances: $\mathrm{Cu}(1)-\mathrm{C}(10)$ 2.048(4) $\AA$; $\mathrm{Cu}(1)-\mathrm{C}(11)$ 2.232(4) $\AA_{;}$ $\mathrm{Cu}(1)-\mathrm{Ti}(1)$ 2.8064(11) $\AA$; $\mathrm{Cu}(1)-\mathrm{Br}(1) 2.2818(8) \AA ̊ \AA \mathrm{C}(10)-$ $\mathrm{C}(11)$ 1.231(6) $\AA ; \mathrm{Ti}(1)-\mathrm{C}(10) 2.075(4) \AA$; $\mathrm{Ti}(1)-\mathrm{C}(1) 2.397(4)$ Å; $\operatorname{Ti}(1)-C(2)$ 2.344(4) $\AA ; \operatorname{Ti}(1)-C(3)$ 2.344(4) $\AA ; \operatorname{Ti}(1)-C(4)$

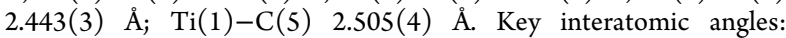
$\mathrm{C}(10)-\mathrm{Ti}-\mathrm{C}(10 \mathrm{a}) \quad 93.4(2)^{\circ} ; \mathrm{Ti}(1)-\mathrm{C}(10)-\mathrm{C}(11) \quad 167.3(3)^{\circ}$; $\mathrm{C} \mathrm{p}_{\text {centroid }}-\mathrm{Ti}(1)-\mathrm{Cp}_{\text {centroid }} 135.8^{\circ}$.

S1 and Figures S3, S4). The structure clearly shows nearly ideal $\eta^{5}$ coordination of the Ind ligands to $\mathrm{Ti}$ as indicated by two key distortion parameters: the slip fold parameter, $\Delta$, which is the difference in average $\mathrm{M}-\mathrm{C}$ bond distances to the ring junction carbons, $\mathrm{C}(4)$ and $\mathrm{C}(5)$, vs the adjacent carbons $\mathrm{C}(1)$ and $\mathrm{C}(3)$; and the hinge angle, HA, defined as the angle between the planes defined by $[\mathrm{C}(1), \mathrm{C}(2), \mathrm{C}(3)]$ and $[\mathrm{C}(1)$, $\mathrm{C}(3), \mathrm{C}(4), \mathrm{C}(5)]$. Indenyl complexes are considered to exhibit $\eta^{5}$ coordination if $\Delta$ and $\mathrm{HA}$ are less than $0.25 \AA$ and $10^{\circ}$, respectively. ${ }^{6,21,22}$ For $\operatorname{Ind}_{2} \mathrm{Ti}\left(\mathrm{C}_{2} \mathrm{Fc}\right)_{2} \mathrm{CuBr}, \Delta=0.10 \AA$, and $\mathrm{HA}=3.1^{\circ}$. The additional steric bulk of the fused benzo ring has only a small impact on the bond angle between the $\mathrm{Ti}$ and the two $\mathrm{C}_{5}$ centroids. Chiefly, it has expanded from $134.5^{\circ}$ in $\mathrm{Cp}_{2} \mathrm{Ti}\left(\mathrm{C}_{2} \mathrm{Fc}\right)_{2} \mathrm{CuBr}^{16}$ to $135.8^{\circ}$ in the analogous Ind complex. There exists a corresponding expansion of the $\mathrm{C}(10)-\mathrm{Ti}-\mathrm{C}(10 \mathrm{a})$ bond angle from $91.13(10)^{\circ}$ to $93.4(2)^{\circ}$ and thus a shortening of the $\mathrm{Ti}-\mathrm{Cu}$ distance from $2.8901(6)$ to 2.8064(11) A. The molecule itself has twofold rotational symmetry. Packing of molecules (Supporting Information, Figure S4) occurs primarily through weak intermolecular C$\mathrm{H} \cdots \pi$ interactions between $\mathrm{Fc}$ and Ind ligands along the $a$-axis, as well as weak intermolecular $\mathrm{C}-\mathrm{H} \cdots \mathrm{Br}$ interactions along the $b$-axis.

The UV-vis absorption spectra for both $\operatorname{Ind}_{2} \mathrm{Ti}\left(\mathrm{C}_{2} \mathrm{Fc}\right)_{2}$ and Ind $_{2} \mathrm{Ti}\left(\mathrm{C}_{2} \mathrm{Fc}\right)_{2} \mathrm{CuBr}$, in $\mathrm{CH}_{2} \mathrm{Cl}_{2}$ (Figure 6), show the presence of two absorptions in the visible region. By analogy with the $\mathrm{Cp}_{2} \mathrm{Ti}\left(\mathrm{C}_{2} \mathrm{Fc}\right)_{2}$ complexes, ${ }^{15}$ the absorptions near $400 \mathrm{~nm}$ are assigned to an Ind to Ti LMCT and the absorptions near 600 $\mathrm{nm}$ assigned to an $\mathrm{Fe}^{\mathrm{II}}$ to $\mathrm{Ti}^{\mathrm{IV}}$ MMCT. As with other complexes in this series, the coordination of $\mathrm{CuBr}$ results in a slight redshift and attenuation of the molar absorptivity. ${ }^{16}$

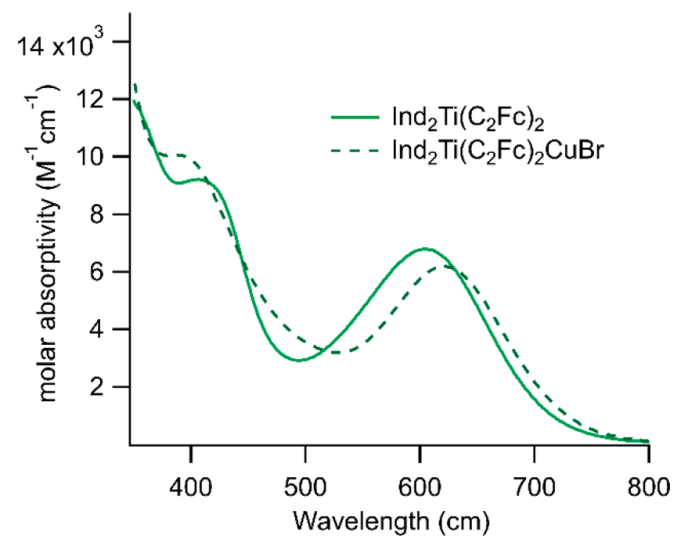

Figure 6. UV-vis absorption spectra in $\mathrm{CH}_{2} \mathrm{Cl}_{2}$ of $\operatorname{Ind}_{2} \mathrm{Ti}\left(\mathrm{C}_{2} \mathrm{Fc}\right)_{2}$ and $\operatorname{Ind}_{2} \mathrm{Ti}\left(\mathrm{C}_{2} \mathrm{Fc}\right)_{2} \mathrm{CuBr}$.

Similar behavior is observed in THF (Supporting Information, Figure S5).

Electrochemistry. The voltammogram of $\mathrm{Cp}_{2} \mathrm{Ti}\left(\mathrm{C}_{2} \mathrm{Fc}\right)_{2}$ has been previously reported and shows a chemically reversible $\mathrm{Ti}^{\mathrm{IV} / \mathrm{III}}$ reduction in the cathodic scan. ${ }^{15}$ The anodic scan reveals a chemically irreversible $2 \mathrm{e}^{-} \mathrm{Fe}^{\mathrm{III} / \mathrm{II}}$ couple followed by a chemically reversible $2 \mathrm{e}^{-}$couple (Figure 7 , bottom). The

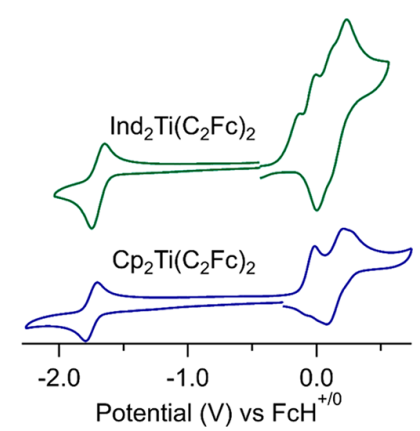

Figure 7. Cyclic voltammogram of $\operatorname{Ind}_{2} \mathrm{Ti}\left(\mathrm{C}_{2} \mathrm{Fc}\right)_{2}$ (top) and $\mathrm{Cp}_{2} \mathrm{Ti}\left(\mathrm{C}_{2} \mathrm{Fc}\right)_{2}$ (bottom), $1 \mathrm{mM}$ in $\mathrm{CH}_{2} \mathrm{Cl}_{2}\left(0.1 \mathrm{M} \mathrm{n}\right.$ - $\left.\mathrm{Bu}_{4} \mathrm{NClO}_{4}\right)$, glassy carbon working electrode, $\mathrm{Ag}^{+/ 0}$ reference electrode, $\mathrm{Pt}$ auxiliary electrode, scan rate $=100 \mathrm{mV} / \mathrm{s}, \mathrm{N}_{2}$ purged. Cyclic voltammograms of $\mathrm{FcH}$ are recorded before and after the cyclic voltammogram and the potentials are corrected for the potential of $\mathrm{FcH}^{+/ 0} \mathrm{vs} \mathrm{Ag}^{+/ 0}$. Due to the irreversibility in both the cathodic and anodic scans of $\operatorname{Ind}_{2} \mathrm{Ti}\left(\mathrm{C}_{2} \mathrm{Fc}\right)_{2}$, each direction for that complex is recorded separately.

irreversible nature of this first oxidation has been attributed to subsequent rapid heterolytic $\mathrm{Ti}-\mathrm{C}$ bond cleavage. ${ }^{15,23,24}$ During this cleavage, $1 \mathrm{e}^{-}$from each $\mathrm{Ti}-\mathrm{C}$ bond serves to reduce $\mathrm{Fc}^{+}$back to $\mathrm{Fc}$, while the remaining $\mathrm{e}^{-}$is involved in the formation of a new $\mathrm{C}-\mathrm{C}$ bond to generate $\mathrm{FcC}_{4} \mathrm{Fc}$ (eq 1 ). The reversible oxidation of $\mathrm{FcC}_{4} \mathrm{Fc}$ appears slightly anodic of the first irreversible oxidation and consists of two closely spaced $1 \mathrm{e}^{-} \mathrm{Fe}^{\mathrm{II} / \mathrm{III}}$ oxidations.

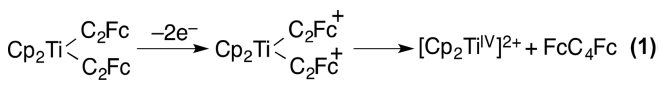

The cyclic voltammogram of $\operatorname{Ind}_{2} \mathrm{Ti}\left(\mathrm{C}_{2} \mathrm{Fc}\right)_{2}$ shows some notable differences (Figure 7, top). First, the $\mathrm{Ti}^{\mathrm{IV} / \mathrm{III}}$ reduction is no longer chemically reversible, with $i_{\mathrm{pa}} / i_{\mathrm{pc}}<1$. A scan rate dependence (Supporting Information, Figure S6) shows that 
$i_{\mathrm{pa}} / i_{\mathrm{pc}}$ approaches unity with increased scan rate $(10 \mathrm{mV} / \mathrm{s}$ to $500 \mathrm{mV} / \mathrm{s}$ ), suggesting an EC mechanism. Second, rather than a single irreversible $2 \mathrm{e}^{-} \mathrm{Fe}^{\mathrm{III} / \mathrm{II}}$ wave in the anodic scan prior to the $\mathrm{FcC}_{4} \mathrm{Fc}$ oxidation, two waves are observed with similar currents to the $1 \mathrm{e}^{-} \mathrm{Ti}^{\mathrm{IV} / \mathrm{III}}$ reduction. Thus, these are ascribed to $1 \mathrm{e}^{-}$oxidations. An anodic scan of $\mathrm{Ind}_{2} \mathrm{TiCl}_{2}$ shows no features in this potential range, suggesting that these waves must both be due to the oxidation of Fc. Reversing the scan after each of these oxidations demonstrates that each is chemically irreversible (Supporting Information, Figure S7). The reversible wave at anodic potentials to these two irreversible waves resembles that of $\mathrm{FcC}_{4} \mathrm{Fc}$. Indeed, spiking the solution with a sample of $\mathrm{FcC}_{4} \mathrm{Fc}$ supports the assignment of $\mathrm{FcC}_{4} \mathrm{Fc}$ as the product of the irreversible oxidations. Third, for the Ind complex relative to the $\mathrm{Cp}$ complex, there is an anodic shift of the $\mathrm{Ti}^{\mathrm{IV} / \mathrm{III}}$ potential but a cathodic shift of the $\mathrm{Fe}^{\mathrm{III} / \mathrm{II}}$ potential (Figure 7 and vide infra).

As has been observed previously for ${ }^{\mathrm{R}} \mathrm{Cp}_{2} \mathrm{Ti}\left(\mathrm{C}_{2} \mathrm{Fc}\right)_{2}$ complexes, ${ }^{16}$ coordination of $\mathrm{CuBr}$ to $\operatorname{Ind}_{2} \mathrm{Ti}\left(\mathrm{C}_{2} \mathrm{Fc}\right)_{2}$ stabilizes the complex toward oxidation, resulting in the observation of two separate, chemically reversible, $1 \mathrm{e}^{-}$oxidations in the cyclic voltammograms (Figure 8, Table 1). The absence of an anodic

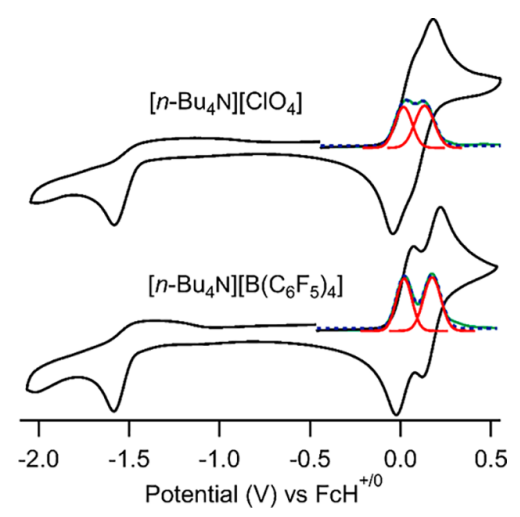

Figure 8. CVs and DPVs for $\operatorname{Ind}_{2} \mathrm{Ti}\left(\mathrm{C}_{2} \mathrm{Fc}\right)_{2} \mathrm{CuBr}$ with two different supporting electrolytes. Other than supporting electrolyte, conditions are the same as described in Figure 7. For the DPV insets, the green line is the experimental DPV, the red lines correspond to the individual Gaussian fits used to fit the data, and the dashed line represents the sum of the individual Gaussian fits.

Table 1. Fe ${ }^{\mathrm{III} / \mathrm{II}}$ Potentials for $\mathrm{Ind}_{2} \mathrm{Ti}\left(\mathrm{C}_{2} \mathrm{Fc}\right)_{2} \mathrm{CuBr}$ and $\mathrm{Cp}_{2} \mathrm{Ti}\left(\mathrm{C}_{2} \mathrm{Fc}\right)_{2} \mathrm{CuBr}$ with Different Supporting Electrolytes

\begin{tabular}{llcc}
\multicolumn{1}{c}{ compound } & \multicolumn{1}{c}{ electrolyte } & $E_{1 / 2}(1)^{a, b}$ & $E_{1 / 2}(2)^{a, b}$ \\
$\mathrm{Ind}_{2} \mathrm{Ti}\left(\mathrm{C}_{2} \mathrm{Fc}\right)_{2} \mathrm{CuBr}$ & {$\left[n-\mathrm{Bu}_{4} \mathrm{~N}\right]\left[\mathrm{ClO}_{4}\right]$} & 0.018 & 0.134 \\
$\mathrm{Ind}_{2} \mathrm{Ti}\left(\mathrm{C}_{2} \mathrm{Fc}\right)_{2} \mathrm{CuBr}$ & {$\left[n-\mathrm{Bu}_{4} \mathrm{~N}\right]\left[\mathrm{B}\left(\mathrm{C}_{6} \mathrm{~F}_{5}\right)_{4}\right]$} & 0.021 & 0.176 \\
$\mathrm{Cp}_{2} \mathrm{Ti}\left(\mathrm{C}_{2} \mathrm{Fc}\right)_{2} \mathrm{CuBr}$ & {$\left[n-\mathrm{Bu}_{4} \mathrm{~N}\right]\left[\mathrm{ClO}_{4}\right]$} & 0.024 & 0.137 \\
$\mathrm{Cp}_{2} \mathrm{Ti}\left(\mathrm{C}_{2} \mathrm{Fc}\right)_{2} \mathrm{CuBr}^{c}$ & {$\left[n-\mathrm{Bu}_{4} \mathrm{~N}\right]\left[\mathrm{B}\left(\mathrm{C}_{6} \mathrm{~F}_{5}\right)_{4}\right]$} & 0.016 & 0.160
\end{tabular}

${ }^{a}$ All electrochemical $E_{1 / 2}$ values are from Gaussian fits of the DPV. ${ }^{b}$ All potentials are reported vs $\mathrm{FcH}^{+/ 0}$. ${ }^{c}$ From ref 16 .

feature in the analogous voltammogram for $\mathrm{Cp}_{2} \mathrm{Ti}$ $\left(\mathrm{C}_{2} \mathrm{Ph}\right)_{2} \mathrm{CuBr}^{16}$ precludes ascribing either feature in $\mathrm{Ind}_{2} \mathrm{Ti}-$ $\left(\mathrm{C}_{2} \mathrm{Fc}\right)_{2} \mathrm{CuBr}$ to a $\mathrm{Cu}{ }^{\mathrm{II} / \mathrm{I}}$ redox couple. Thus, these are ascribed to two separate $\mathrm{Fe}^{\mathrm{III} / \mathrm{II}}$ couples, indicating some degree of electronic communication between the two redox-active sites. When the supporting electrolyte, $\left[n-\mathrm{Bu}_{4} \mathrm{~N}\right]\left[\mathrm{ClO}_{4}\right]$, is replaced with $\left[n-\mathrm{Bu}_{4} \mathrm{~N}\right]\left[\mathrm{B}\left(\mathrm{C}_{6} \mathrm{~F}_{5}\right)_{4}\right]$, the redox splitting, as measured by the differential pulse voltammograms (DPV), increases from
$116 \mathrm{mV}$ to $155 \mathrm{mV}$. This increased redox splitting in the presence of a less coordinating supporting electrolyte is typically interpreted in terms of increased electrostatic (through-space) interactions that occur between the redox active termini when ion-paring between the supporting electrolyte and the oxidized species is decreased (i.e., ion pairing with $\mathrm{B}\left(\mathrm{C}_{6} \mathrm{~F}_{5}\right)_{4}{ }^{-}$is weaker than with $\left.\mathrm{ClO}_{4}{ }^{-}\right) .{ }^{16,25,26}$

\section{DISCUSSION}

The majority of features observed for $\operatorname{Ind}_{2} \mathrm{Ti}\left(\mathrm{C}_{2} \mathrm{Fc}\right)_{2}$ and Ind $_{2} \mathrm{Ti}\left(\mathrm{C}_{2} \mathrm{Fc}\right)_{2} \mathrm{CuBr}$ have been observed for other complexes in the ${ }^{\mathrm{R}} \mathrm{Cp}_{2} \mathrm{Ti}\left(\mathrm{C}_{2} \mathrm{Fc}\right)_{2}$ series. ${ }^{15,16}$ These are briefly discussed, followed by a focus on the peculiar nature of the redox potentials of the first oxidation and reduction of the parent Ind $_{2} \mathrm{Ti}\left(\mathrm{C}_{2} \mathrm{Fc}\right)_{2}$.

Like all of the complexes in this series, oxidation of $\operatorname{Ind}_{2} \operatorname{Ti}\left(\mathrm{C}_{2} \mathrm{Fc}\right)_{2}$ is followed by rapid decomposition on the electrochemical time scale to give the electrochemically active $\mathrm{FcC}_{4} \mathrm{Fc}$. The complex can be stabilized by binding of $\mathrm{CuBr}$ between the alkynes. The $\operatorname{Ind}_{2} \mathrm{Ti}\left(\mathrm{C}_{2} \mathrm{Fc}\right)_{2} \mathrm{CuBr}$ complex shows two separate and reversible $1 \mathrm{e}^{-}$waves corresponding to the sequential oxidation of the two Fc termini. The redox splitting is in the same range as those observed for other complexes in the ${ }^{\mathrm{R}} \mathrm{Cp}_{2} \mathrm{Ti}\left(\mathrm{C}_{2} \mathrm{Fc}\right)_{2} \mathrm{CuBr}$ series. ${ }^{16}$ For those complexes, no evidence of electronic coupling in the form of an $\mathrm{Fe}^{\mathrm{II}} / \mathrm{Fe}^{\mathrm{III}}$ intervalence charge-transfer (IVCT) band was observed. Thus, the possibilities of through-space interactions, inductive effects, and stepwise coupling through a redox-active bridge were hypothesized. ${ }^{16}$ For that series, a correlation was observed between the magnitude of the redox-splitting and the electrondensity on the titanocene. For example, the magnitude of the redox-splitting was greater for the more electron-rich titanocene, $\mathrm{Cp}{ }_{2}{ }_{2} \mathrm{Ti}\left(\mathrm{C}_{2} \mathrm{Fc}\right)_{2} \mathrm{CuBr}$, than for $\mathrm{Cp}_{2} \mathrm{Ti}\left(\mathrm{C}_{2} \mathrm{Fc}\right)_{2} \mathrm{CuBr}$ $\left(163 \mathrm{mV}\right.$ vs $144 \mathrm{mV}$ with $\left[n-\mathrm{Bu}_{4} \mathrm{~N}\right]\left[\mathrm{B}\left(\mathrm{C}_{6} \mathrm{~F}_{5}\right)_{4}\right]$ as the supporting electrolyte). ${ }^{16}$ Given that the redox splitting for Ind ${ }_{2} \mathrm{Ti}\left(\mathrm{C}_{2} \mathrm{Fc}\right)_{2} \mathrm{CuBr}$ is $155 \mathrm{mV}$ under the same conditions, that would suggest that Ind lies between $\mathrm{Cp}^{*}$ and $\mathrm{Cp}$ in terms of its electron donor properties, consistent with summaries of photoelectron spectroscopy and redox potentials for oxidation of $\eta^{5}$-indenyl complexes.

One notable difference between the electrochemistry of Ind $\mathrm{Ti}_{2}\left(\mathrm{C}_{2} \mathrm{Fc}\right)_{2}$ and others in the ${ }^{\mathrm{R}} \mathrm{Cp}_{2} \mathrm{Ti}\left(\mathrm{C}_{2} \mathrm{Fc}\right)_{2}$ series is that rather than observing a single $2 \mathrm{e}^{-}$wave for the simultaneous oxidation of the two $\mathrm{Fc}$ termini, two $1 \mathrm{e}^{-}$waves are observed. The first of these two oxidations can be assumed to be the oxidation of one of the $\mathrm{Fc}$ ligands of intact $\operatorname{Ind}_{2} \mathrm{Ti}\left(\mathrm{C}_{2} \mathrm{Fc}\right)_{2}$. However, because this oxidation is irreversible, the species remaining at the electrode surface are no longer defined. Thus, the identity of the species being oxidized in the second irreversible oxidation wave is not known. It is likely that one or both ethynylferrocene ligands rapidly dissociate after the first oxidation. Thus, the second wave is presumably the oxidation of a dissociated ethynylferrocene or a bound ethynylferrocene after only one has dissociated. It is unclear why the Ind ligand results in this separation in potentials that is not observed for any of the other ${ }^{\mathrm{R}} \mathrm{Cp}_{2} \mathrm{Ti}\left(\mathrm{C}_{2} \mathrm{Fc}\right)_{2}$ complexes. Previous reports have interpreted the $2 \mathrm{e}^{-}$wave for these previously characterized ${ }^{\mathrm{R}} \mathrm{Cp}_{2} \mathrm{Ti}\left(\mathrm{C}_{2} \mathrm{Fc}\right)_{2}$ complexes in terms of there being no electronic communication between the two Fc termini, and no intermediate decomposition step. ${ }^{15,16,23,24}$

Regardless of the nature of this difference in behavior, the potentials of the first oxidation step for each complex can be compared. For the $\mathrm{Cp}^{*}{ }^{15}$ Ind, and $\mathrm{Cp}^{15}$ complexes, the $\mathrm{Fe}^{\mathrm{III} / \mathrm{II}}$ 
potentials are $-0.22,-0.21$, and $-0.08 \mathrm{~V}$, respectively. This is again consistent with Ind being a superior donor ligand to $\mathrm{Cp}$ and a slightly weaker donor than $\mathrm{Cp}^{*}$, and there being an inductive effect on the $\mathrm{Fe}^{\mathrm{III} / \mathrm{II}}$ potential. Furthermore, this is consistent with literature reports where the oxidation of Ind metal complexes always occurs at more cathodic potentials than the corresponding $\mathrm{Cp}$ complexes (Table 2). Not surprisingly, the coordination of $\mathrm{CuBr}$ mitigates this inductive potential difference (Table 1) as has been observed for other complexes in this series. $^{15,16}$

Table 2. Comparison of Electrochemical Potentials for $\mathrm{Cp}$ and Ind Complexes ${ }^{a}$

\begin{tabular}{|c|c|c|c|c|c|}
\hline compound & ox & red & solvent & electrolyte & ref \\
\hline $\mathrm{CpRuCl}\left(\mathrm{PPh}_{3}\right)_{2}$ & 0.56 & - & $\mathrm{CH}_{2} \mathrm{Cl}_{2}$ & TBAPF $_{6}$ & 11 \\
\hline $\operatorname{IndRuCl}\left(\mathrm{PPh}_{3}\right)_{2}$ & 0.45 & - & $\mathrm{CH}_{2} \mathrm{Cl}_{2}$ & $\mathrm{TBAPF}_{6}$ & 11 \\
\hline $\mathrm{Cp}_{2} \mathrm{Fe}$ & 0.49 & - & $\mathrm{CH}_{2} \mathrm{Cl}_{2}$ & $\mathrm{TBAClO}_{4}$ & 27 \\
\hline IndCpFe & 0.35 & - & $\mathrm{CH}_{2} \mathrm{Cl}_{2}$ & $\mathrm{TBAClO}_{4}$ & 27 \\
\hline $\operatorname{Ind}_{2} \mathrm{Fe}$ & 0.21 & - & $\mathrm{CH}_{2} \mathrm{Cl}_{2}$ & $\mathrm{TBAClO}_{4}$ & 27 \\
\hline $\mathrm{Cp}_{2} \mathrm{Ru}$ & 0.99 & - & $\mathrm{CH}_{2} \mathrm{Cl}_{2}$ & TBATFPB $^{b}$ & 28 \\
\hline IndCpRu & 0.77 & - & $\mathrm{CH}_{2} \mathrm{Cl}_{2}$ & $\mathrm{TBAPF}_{6}$ & 29 \\
\hline $\mathrm{Ind}_{2} \mathrm{Ru}$ & 0.55 & - & $\mathrm{CH}_{2} \mathrm{Cl}_{2}$ & $\mathrm{TBAPF}_{6}$ & 29 \\
\hline $\mathrm{Cp}_{2} \mathrm{Os}$ & 0.79 & - & $\mathrm{CH}_{2} \mathrm{Cl}_{2}$ & TBATFPB $^{b}$ & 28 \\
\hline $\mathrm{Ind}_{2} \mathrm{Os}$ & 0.43 & - & $\mathrm{CH}_{2} \mathrm{Cl}_{2}$ & $\mathrm{TBAPF}_{6}$ & 29 \\
\hline$\left[\mathrm{Cp}_{2} \mathrm{Co}\right]\left[\mathrm{ClO}_{4}\right]$ & - & -1.16 & $\mathrm{H}_{2} \mathrm{O}$ & $\mathrm{NaClO}_{4}$ & 12 \\
\hline$\left[\mathrm{Ind}_{2} \mathrm{Co}\right]\left[\mathrm{ClO}_{4}\right]^{c}$ & - & -0.6 & $\mathrm{H}_{2} \mathrm{O}$ & $\mathrm{NaClO}_{4}$ & 12 \\
\hline$\left[\mathrm{Cp}_{2} \mathrm{Co}\right]\left[\mathrm{PF}_{6}\right]$ & - & -0.94 & $\mathrm{CH}_{3} \mathrm{CN}$ & TBAPF $_{6}$ & 30 \\
\hline$\left[\mathrm{Ind}_{2} \mathrm{Co}\right]\left[\mathrm{CF}_{3} \mathrm{CO}_{2}\right]$ & - & -0.51 & $\mathrm{CH}_{3} \mathrm{CN}$ & $\mathrm{TBAClO}_{4}$ & 31 \\
\hline$\left[\mathrm{Cp}_{2} \mathrm{~V}(\mathrm{CO})_{2}\right]\left[\mathrm{PF}_{6}\right]^{d}$ & - & -0.93 & THF & $\mathrm{TBAPF}_{6}$ & 14 \\
\hline$\left[\operatorname{Ind}_{2} \mathrm{~V}(\mathrm{CO})_{2}\right]\left[\mathrm{PF}_{6}\right]$ & - & -0.56 & THF & $\mathrm{TBAPF}_{6}$ & 14 \\
\hline $\mathrm{Cp}_{2} \mathrm{~V}^{e}$ & - & -2.72 & THF & TBAPF $_{6}$ & 14 \\
\hline $\operatorname{Ind}_{2} \mathrm{~V}^{d, e}$ & - & -2.38 & THF & $\mathrm{TBAClO}_{4}$ & 14 \\
\hline $\mathrm{Cp}_{2} \mathrm{Ti}\left(\mathrm{CH}_{3}\right)_{2}{ }^{c}$ & - & -2.0 & THF & $\mathrm{TBAPF}_{6}$ & 13 \\
\hline $\operatorname{Ind}_{2} \mathrm{Ti}\left(\mathrm{CH}_{3}\right)_{2}{ }^{c, d}$ & - & -1.9 & THF & $\mathrm{TBAPF}_{6}$ & 13 \\
\hline $\operatorname{IndTiCl}_{3}^{f}$ & - & -0.82 & $\mathrm{CH}_{2} \mathrm{Cl}_{2}$ & TBAPF $_{6}$ & 32 \\
\hline $\mathrm{CpTiCl}_{3}^{f}$ & - & -0.82 & $\mathrm{CH}_{2} \mathrm{Cl}_{2}$ & TBAPF $_{6}$ & 32 \\
\hline
\end{tabular}

${ }^{a}$ Potentials vs SCE unless otherwise indicated. ${ }^{b}$ TBATFPB $=$ Tetrabutylammonium tetrakis[3,5-bis(trifluoromethyl)phenyl]borate. ${ }^{c}$ Only reported to nearest $0.1 \mathrm{~V}$. ${ }^{d}$ Irreversible. ${ }^{e}$ Potential vs silver wire

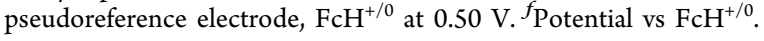

Perhaps the most perplexing result is that the $\mathrm{Ti}^{\mathrm{IV} / \mathrm{III}}$ potential for $\operatorname{Ind}_{2} \mathrm{Ti}\left(\mathrm{C}_{2} \mathrm{Fc}\right)_{2}$ is shifted anodically relative to the analogous $\mathrm{Cp}$ complex, suggesting that Ind is a poorer $\mathrm{e}^{-}$ donor than $\mathrm{Cp}$. Thus, within the same complex, substituting $\mathrm{Cp}$ with Ind has shifted the $\mathrm{Ti}{ }^{\mathrm{IV} / \mathrm{III}}$ potential anodically while the $\mathrm{Fe}^{\mathrm{III} / \mathrm{II}}$ potential is shifted cathodically. For every complex in this series except Ind $2 \mathrm{Ti}\left(\mathrm{C}_{2} \mathrm{Fc}\right)_{2}$, both potentials shift in the same direction relative to the parent complex, $\mathrm{Cp}_{2} \mathbf{T i}\left(\mathrm{C}_{2} \mathbf{F c}\right)_{2}$ (Table 3 ). This includes not only complexes where $\mathrm{R}$ groups on the $\mathrm{Cp}$ ring of the titanocene have been used to tune the electron density, but also where one of the two $\mathrm{C}_{2} \mathrm{Fc}$ ligands has been replaced by a more electron withdrawing, substituted alkyne ligand, $\mathrm{C}_{2} \mathrm{R}^{\prime}$ (Figure 2). This has been interpreted as an inductive effect through the $\mathrm{Ti}$, i.e., ligand induced changes in $\mathrm{e}^{-}$density at $\mathrm{Ti}^{\mathrm{IV}}$ induce the same effect (albeit to a lesser degree) through the ethynyl bridge to the Fc.

As counterintuitive as it seems for Ind to produce an anodic shift of the Ti-centered reduction relative to $\mathrm{Cp}$, a search of the literature shows this to be a general phenomenon (Table 2). In all but one of the reports we found, there was an Ind induced anodic shift ( 0.1 to $0.5 \mathrm{~V})$. Only $\mathrm{CpTiCl}_{3}$ did not follow this
Table 3. Redox Potentials for Complexes Discussed Herein ${ }^{a}$

\begin{tabular}{lcc}
\multicolumn{1}{c}{ complex } & $E_{1 / 2}\left(\mathrm{Ti}^{\mathrm{IV} / \mathrm{III}}\right)$ & $E_{1 / 2}\left(\mathrm{Fe}^{\mathrm{III} / \mathrm{II}}\right)$ \\
$\mathrm{Cp}^{*}{ }_{2} \mathrm{Ti}\left(\mathrm{C}_{2} \mathrm{Fc}\right)_{2}$ & -2.28 & $-0.22^{b}$ \\
$\mathrm{Cp}_{2} \mathrm{Ti}\left(\mathrm{C}_{2} \mathrm{Fc}\right)_{2}$ & $-\mathbf{1 . 7 5}$ & $-0.08^{b}$ \\
${ }_{\mathrm{TMS}} \mathrm{Cp}_{2}\left(\mathrm{C}_{2} \mathrm{Fc}\right)\left(\mathrm{C}_{2} \mathrm{PhCF}_{3}\right)$ & -1.67 & $0.00^{b}$ \\
${ }^{\mathrm{TMS}} \mathrm{Cp}_{2}\left(\mathrm{C}_{2} \mathrm{Fc}\right)\left(\mathrm{C}_{2} \mathrm{CF}_{3}\right)$ & -1.54 & 0.05 \\
${ }^{\mathrm{MeOOC}} \mathrm{Cp}_{2}\left(\mathrm{C}_{2} \mathrm{Fc}\right)_{2}$ & -1.46 & $-0.03^{b}$ \\
${ }_{\mathrm{Ind}} \mathrm{Ti}_{2}\left(\mathrm{C}_{2} \mathrm{Fc}\right)_{2}$ & $-1.70^{c}$ & $-0.21^{b, d}$
\end{tabular}

${ }^{a}$ Conditions given in Figure $7 .{ }^{b}$ Irreversible wave. $E_{1 / 2}$ estimated as the half-wave potential. ${ }^{c}$ Partially reversible wave. ${ }^{d}$ Potential for the first oxidation.

pattern, exhibiting no $\mathrm{Ti}^{\mathrm{IV} / \mathrm{III}}$ potential shift upon replacement of $\mathrm{Cp}$ with Ind. ${ }^{32}$ Thus, the literature is consistent with what we have observed with respect to both a cathodic shift of the oxidation and an anodic shift of the reduction upon replacement of $\mathrm{Cp}$ with Ind. This suggests that the situation is more complex than a simple dependence on an inductive effect.

To unify these seemingly contradictory sets of experimental results, we suggest that the indenyl ligand is indeed more electron-rich (donating) than the $\mathrm{Cp}$ ligand, but that $1 \mathrm{e}^{-}$ reduction in indenyl complexes is accompanied by an $\eta^{5}$ to $\eta^{3}$ ring-slip, stabilizing the reduced form (due to a lowering of the donor number of the ligand from $6 \mathrm{e}^{-}$to $4 \mathrm{e}^{-}$) and resulting in an anodic shift. This obviously requires that $1 \mathrm{e}^{-}$reduction can indeed induce a ring-slip, and also that this ring-slip is rapid on the electrochemical time-scale. There is literature to support both of these factors. The first report of a redox induced $\eta^{5}$ to $\eta^{3}$ haptotropic shift involved the stepwise reduction of $\left(\eta^{5}\right.$ Ind $)_{2} \mathrm{~V}(\mathrm{CO})_{2}{ }^{+14}$ for which the intermediate $1 \mathrm{e}^{-}$reduction product has been structurally characterized as $\left(\eta^{3}-\mathrm{Ind}\right)\left(\eta^{5}\right.$ Ind) $\mathrm{V}(\mathrm{CO})_{2} \cdot{ }^{33}$ Furthermore, cyclic voltammetry suggests that the $\eta^{5}$ to $\eta^{3}$ ring slip equilibrium occurs rapidly on the electrochemical time scale. ${ }^{14}$ Since that first example, several more examples of reductively induced haptotropic shifts of the indenyl ligand have been reported. ${ }^{34,35}$ One particularly interesting example involves the stepwise reduction of $\left(\eta^{5}\right.$ Ind $) \mathrm{Mn}(\mathrm{CO})_{3}$ to its dianion. ${ }^{35}$ The relatively small difference between the first and second reduction potentials $(0.25 \mathrm{~V})$ was taken as evidence that the $1 \mathrm{e}^{-}$reduction intermediate is $\left(\eta^{5}\right.$ Ind) $\mathrm{Mn}(\mathrm{CO})_{3}{ }^{-}$, and the $2 \mathrm{e}^{-}$reduction product is $\left(\eta^{3}-\right.$ Ind) $\mathrm{Mn}(\mathrm{CO})_{3}{ }^{2-}$, having undergone a haptotropic shift that markedly stabilizes the dianionic reaction product. Thus, there is also a literature precedent for an $\eta^{5}$ to $\eta^{3}$ haptotropic shift of the indenyl ligand impacting the redox potential through stabilization of the reduction product.

Given the implication that Ind is more electron-rich than $\mathrm{Cp}$, the effect of the haptotropic shift on the reduction potential must be larger than the effect of the differing donor capacity of Ind vs Cp. Furthermore, one might expect the $\eta^{5} / \eta^{3}$ equilibrium of the reduced species to shift further toward $\eta^{3}$ as the electron count of the metal increases. Indeed, for the aforementioned case where the $1 \mathrm{e}^{-}$reduction product of $\left(\eta^{5}\right.$ Ind $)_{2} \mathrm{~V}(\mathrm{CO})_{2}{ }^{+}$was structurally characterized as $\left(\eta^{3}-\mathrm{Ind}\right)\left(\eta^{5}\right.$ Ind $) \mathrm{V}(\mathrm{CO})_{2}$, the reactant is an $18 \mathrm{e}^{-}$species and reduction without a haptotropic shift would result in a hypervalent $19 \mathrm{e}^{-}$ species. Moreover, the largest anodic shifts of reductions in Table 2 occur for $18 \mathrm{e}^{-}$species. The one case where the reduction potentials for the Ind and $\mathrm{Cp}$ complexes are identical (i.e., IndTiCl ${ }_{3}$ and $\mathrm{CpTiCl}_{3}$ ) involves $12 \mathrm{e}^{-}$species, the lowest $\mathrm{e}^{-}$count in Table 2. However, in the absence of any 
haptotropic shift, one would have expected the reduction of the Ind complex to at least be slightly cathodic of the $\mathrm{Cp}$ complex due to differences in the donor strength. The fact that the redox potentials are the same indicates at least some equilibrium with the reduced $\eta^{5}$ species. Not surprisingly, the $16 \mathrm{e}^{-} \operatorname{Ind}_{2} \mathrm{Ti}\left(\mathrm{C}_{2} \mathrm{Fc}\right)_{2}$ complex investigated herein shows a relatively modest $(50 \mathrm{mV})$ anodic shift of the $\mathrm{Ti}^{\mathrm{IV} / \mathrm{III}}$ reduction relative to its $\mathrm{Cp}$ analogue. One additional hint of a haptotropic shift accompanying the reduction of $\mathrm{Ind}_{2} \mathrm{Ti}$ $\left(\mathrm{C}_{2} \mathrm{Fc}\right)_{2}$ is the slight irreversibility of the $\mathrm{Ti}^{\mathrm{IV} / \mathrm{III}}$ reduction wave, whereas this reduction is chemically reversible for all other complexes in the ${ }^{\mathrm{R}} \mathrm{Cp}_{2} \mathrm{Ti}\left(\mathrm{C}_{2} \mathrm{Fc}\right)_{2}$ series. ${ }^{15,17,23}$ Such irreversibility may be due to increased vulnerability to substitution upon an $\eta^{5}$ to $\eta^{3}$ ring slip, which could lead to decomposition.

The energy of the MMCT transition is worthy of discussion within the context of the ground and excited state potentialenergy wells (Figure 9) showing the relationship between the

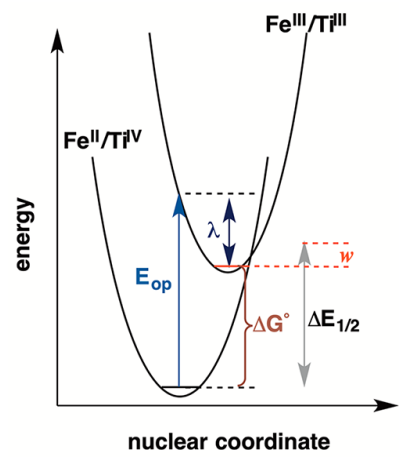

Figure 9. Potential well diagram showing relationship between observed electrochemical and optical parameters. Modified from ref 15.

energies of the vertical optical transition, $E_{\text {op }}$, the thermal transition, $\Delta G^{\circ}$, and the reorganization energy, $\lambda$, which can be estimated from the full-width at half-maximum, $\Delta \nu_{1 / 2}$, of the MMCT band (eq 2). ${ }^{15,36}$ Figure 9 shows that subtraction of $\lambda$ from $E_{\text {op }}$ gives $\Delta G^{\circ}$.

$$
\lambda=\left(\Delta v_{1 / 2}\right)^{2} / 2310 \mathrm{~cm}^{-1}
$$

These values for $\Delta G^{\circ}$ are compared with $\Delta E_{1 / 2}$, the potential difference between the $\mathrm{Fe}^{\mathrm{III} / \mathrm{II}}$ couple and the $\mathrm{Ti}{ }^{\mathrm{IV} / \mathrm{III}}$ couple (Table 4). Given the smaller value of $\Delta E_{1 / 2}$ for Ind $_{2} \mathrm{Ti}\left(\mathrm{C}_{2} \mathrm{Fc}\right)_{2}$ vs the $\mathrm{Cp}$ analogue, it is not surprising that the $\mathrm{Fe}^{\mathrm{II}}$ to $\mathrm{Ti}^{\mathrm{IV}} \mathrm{MMCT}$ absorption for the Ind complex is red- shifted compared to the Cp complex $\left(16450 \mathrm{~cm}^{-1}\right.$ vs 17120 $\mathrm{cm}^{-1}$ ).

It is also important to point out that, although $\Delta E_{1 / 2}$ reasonably approximates $\Delta G^{\circ}$, it fails to account for the modified electrostatic interactions in the excited state. ${ }^{37,38}$ That is, $\Delta E_{1 / 2}$ is the energy difference between the ground state and a state where the electron and hole are on different molecules, whereas the optical excited state has the electron and hole on the same molecule. The attractive interaction between an electron and a hole suggests that $\Delta E_{1 / 2}$ should overestimate $\Delta G^{\circ}$ and approach zero as the charge separation distance increases. For previously studied complexes in this series, ${ }^{15}$ the difference between $\Delta E_{1 / 2}$ and $\Delta G^{\circ}$, a Coulombic energy correction work term, $w$ (Figure 9), is in a very similar range to those calculated for ferrocene to acceptor charge transfer through an ethylene bridge, ${ }^{37}$ always being positive (Table 4). ${ }^{15}$ However, for $\operatorname{Ind}_{2} \operatorname{Ti}\left(\mathrm{C}_{2} \mathrm{Fc}\right)_{2}, \Delta E_{1 / 2}$ underestimates $\Delta G^{\circ}$ by $70 \mathrm{mV}$, resulting in a negative value for $w$. A possible explanation for this anomalous behavior employs the hypothesis that the $\mathrm{Ti}^{\mathrm{iV} / \mathrm{III}}$ reduction potential for $\mathrm{Ind}_{2} \mathrm{Ti}$ $\left(\mathrm{C}_{2} \mathrm{Fc}\right)_{2}$ is anodically shifted because of the $\eta^{5}$ to $\eta^{3}$ haptotropic shift. Thus, there are likely two excited state potential surfaces: one where both indenyls are in the $\eta^{5}$ configuration and one with one indenyl having undergone a haptotropic shift. The latter will be at a lower energy than the former and further shifted from the ground state equilibrium geometry. As a result, the excited state accessed through the optical transition may be on a different potential surface than the one whose energy is estimated by electrochemical potentials.

\section{CONCLUSIONS}

Two new complexes with $\mathrm{Fe}^{\mathrm{II}}$ to $\mathrm{Ti}^{\mathrm{IV}}$ MMCT transitions, $\operatorname{Ind}_{2} \mathrm{Ti}\left(\mathrm{C}_{2} \mathrm{Fc}\right)_{2}$ and $\operatorname{Ind}_{2} \mathrm{Ti}\left(\mathrm{C}_{2} \mathrm{Fc}\right)_{2} \mathrm{CuBr}$, have been prepared and characterized. Though many of the features of these complexes are similar to those of other ${ }^{\mathrm{R}} \mathrm{Cp}_{2} \mathrm{Ti}\left(\mathrm{C}_{2} \mathrm{Fc}\right)_{2}$ complexes, the electrochemistry hints at some unusual properties resulting from the Ind ligand. Chiefly, relative to the corresponding $\mathrm{Cp}$ complex, the $\mathrm{Ti}^{\mathrm{IV} / \mathrm{III}}$ reduction potential shifts anodically, while the $\mathrm{Fe} \mathrm{II}^{\mathrm{II} / \mathrm{II}}$ potential shifts cathodically. Though some caution should be exercised in interpretation due to the irreversible nature of the Fc centered oxidations, an investigation of the literature shows that this is a general phenomenon. Namely, oxidation processes shift cathodically upon replacement of $\mathrm{Cp}$ with Ind, and reduction processes shift anodically (Table 2). Though the preponderance of literature suggests that Ind is more electron-rich than $\mathrm{Cp}$, some suggest Ind is a poorer donor based on a comparison of reduction potentials. To the best of our knowledge, the complexes discussed herein comprise the first example where the effects of replacing $\mathrm{Cp}$ with Ind on both an oxidation

Table 4. Comparison of Spectroscopic and Electrochemical Parameters in $\mathrm{CH}_{2} \mathbf{C l}_{2}$

\begin{tabular}{|c|c|c|c|c|c|}
\hline complex & $E_{\mathrm{op}}\left(\mathrm{cm}^{-1}\right)$ & $\lambda\left(\mathrm{cm}^{-1}\right)$ & $\Delta G^{\circ}\left(\mathrm{cm}^{-1}\right)$ & $\Delta G^{\circ}(\mathrm{V})$ & $\Delta E_{1 / 2}(w)$ \\
\hline $\mathrm{Cp} *{ }_{2} \mathrm{Ti}\left(\mathrm{C}_{2} \mathrm{Fc}\right)_{2}{ }^{a}$ & 18380 & 2790 & 15600 & 1.93 & $2.06(0.13)$ \\
\hline $\mathrm{Cp}_{2} \mathrm{Ti}\left(\mathrm{C}_{2} \mathrm{Fc}\right)_{2}^{a}$ & 17120 & 4030 & 13100 & 1.62 & $1.67(0.05)$ \\
\hline${ }^{\mathrm{MeOOC}} \mathrm{Cp}_{2} \mathrm{Ti}\left(\mathrm{C}_{2} \mathrm{Fc}\right)_{2}{ }^{b}$ & 15410 & 4880 & 10500 & 1.30 & $1.46(0.16)$ \\
\hline${ }^{\mathrm{TMS}} \mathrm{Cp}_{2} \mathrm{Ti}\left(\mathrm{C}_{2} \mathrm{Fc}\right)\left(\mathrm{C}_{2} \mathrm{PhCF}_{3}\right)^{a}$ & 16860 & 5000 & 11900 & 1.48 & $1.67(0.19)$ \\
\hline${ }^{\mathrm{TMS}} \mathrm{Cp}_{2} \mathrm{Ti}\left(\mathrm{C}_{2} \mathrm{Fc}\right)\left(\mathrm{C}_{2} \mathrm{CF}_{3}\right)^{a}$ & 15870 & 5150 & 10800 & 1.34 & $1.59(0.25)$ \\
\hline $\operatorname{Ind}_{2} \mathrm{Ti}\left(\mathrm{C}_{2} \mathrm{Fc}\right)_{2}$ & 16450 & 3830 & 12620 & 1.56 & $1.49(-0.07)$ \\
\hline
\end{tabular}

${ }^{a}$ Values from ref $15 .{ }^{b}$ Values from ref 17. 
process and reduction process within the same molecule have been compared. These results are in agreement with the literature and suggest that the opposing potential shifts might be a general phenomenon, rather than the direction of the shift being dependent on either the $d$-electron count or total electron count at the metal. We hypothesize that Ind is indeed more electron-rich than $\mathrm{Cp}$, but that an $\eta^{5}$ to $\eta^{3}$ haptotropic shift accompanies reduction, thus stabilizing the product, resulting in an anodic shift of the reduction potential. Such a haptotropic shift is much less likely for the corresponding $\mathrm{Cp}$ complex. Furthermore, because most known indenyl complexes are $\eta^{5}$, no ring-slipping is expected upon oxidation since such a shift would further lower the electron count of the metal. This hypothesis serves to unify seemingly conflicting data in the literature regarding the donor properties of Ind vs $\mathrm{Cp}$ based on electrochemical data. It is worth noting, however, that the complexes for which the potentials of the metalcentered reduction have been measured (Table 2 and the titanocenes characterized herein) are first-row transition metal complexes, and it is unclear whether this analysis would apply with equal force to second- and third-row transition metals.

\section{EXPERIMENTAL SECTION}

Materials and Methods. THF, $\mathrm{Et}_{2} \mathrm{O}$, and $\mathrm{CH}_{2} \mathrm{Cl}_{2}$ were dried and degassed using an Innovative Technology Inc. solvent purification system. All other materials were reagent grade and used as received. Ind $\mathrm{TiCl}_{2}$ was obtained from Aldrich. Reactions were performed under a dry Ar atmosphere implementing standard Schlenk procedures unless otherwise noted. $\mathrm{Cp}_{2} \mathrm{Ti}_{(}\left(\mathrm{C}_{2} \mathrm{Fc}\right)_{2}{ }^{15}$ and $\left[n-\mathrm{Bu}_{4} \mathrm{~N}\right]$ $\left[\mathrm{B}\left(\mathrm{C}_{6} \mathrm{~F}_{5}\right)_{4}\right]^{39}$ were synthesized according to literature procedures. UV-vis absorption spectra were recorded using a Cary-50 spectrophotometer. NMR spectra were obtained using a Varian 400-MR or an INOVA 500 spectrometer. Infrared spectra were measured on solid samples using a PerkinElmer Spectrum 100 series FT-IR spectrometer equipped with an ATR accessory. Cyclic voltammograms were recorded using a Pine Wavenow potentiostat controlled by Aftermath software (Pine Research Instruments). DPVs were obtained using a BASi Epsilon electrochemical workstation and a BASi cell stand. For all electrochemical experiments, the $\mathrm{FcH}^{+/ 0}$ potential was measured before and/or after each experiment and all reported potentials are referenced vs this standard. Elemental analyses were performed by Midwest Microlabs in Indianapolis, IN.

Syntheses. Ind ${ }_{2} T i\left(C_{2} F c\right)_{2}$. An argon-purged oven-dried two-neck round-bottom flask $(25 \mathrm{~mL})$ was charged with ethynlferrocene (199 $\mathrm{mg}, 0.945 \mathrm{mmol})$ and $\mathrm{Et}_{2} \mathrm{O}(8 \mathrm{~mL})$. After the flask was cooled in a dry ice/acetone bath for $10 \mathrm{~min}, n$-butyllithium $(2.5 \mathrm{M}, 380 \mu \mathrm{L}, 0.945$ $\mathrm{mmol}$ ) was added. The flask was removed from the dry ice/acetone bath and the solution stirred for $10 \mathrm{~min}$. $\operatorname{Ind}_{2} \mathrm{TiCl}_{2}(150 \mathrm{mg}, 0.430$ $\mathrm{mmol}$ ) was added and the solution was stirred at room temperature for $4 \mathrm{~h}$. The dark green precipitate was collected using vacuum filtration. The solid was then loaded onto a silica gel column $(1 \mathrm{~cm} \times$ $12 \mathrm{~cm}$ ) and eluted using a $5 \%$ mixture of triethylamine in $\mathrm{CH}_{2} \mathrm{Cl}_{2}$. The dark green band was collected and the solvent removed using rotary evaporation. The solid was dissolved in minimal $\mathrm{CH}_{2} \mathrm{Cl}_{2}$ (2 $\mathrm{mL})$ and precipitated with hexanes $(20 \mathrm{~mL})$. The solid was collected using vacuum filtration, washed with $\mathrm{Et}_{2} \mathrm{O}(1 \mathrm{~mL})$, and dried under vacuum, yielding $126 \mathrm{mg}(42.1 \%)$ of a dark green solid. UV-vis (THF) $\lambda_{\max }(\varepsilon) ; 404$ (8590), 596 (6330). UV-vis $\left(\mathrm{CH}_{2} \mathrm{Cl}_{2}\right) \lambda_{\max }(\varepsilon)$; 407 (9210), 603 (6790). ${ }^{1} \mathrm{H}$ NMR $\left(500 \mathrm{MHz}, \mathrm{C}_{6} \mathrm{D}_{6}\right) \delta 4.00\left(\mathrm{dd}, J_{1}=\right.$ $\left.J_{2}=1.84 \mathrm{~Hz}, 4 \mathrm{H}\right), 4.20(\mathrm{~s}, 10 \mathrm{H}), 4.40\left(\mathrm{dd}, J_{1}=J_{2}=1.84 \mathrm{~Hz}, 4 \mathrm{H}\right)$ $6.17(\mathrm{~d}, J=3.09 \mathrm{~Hz}, 4 \mathrm{H}), 6.20(\mathrm{t}, J=3.09, \mathrm{~Hz}, 2 \mathrm{H}), 7.00\left(\mathrm{dd}, J_{1}=3.0\right.$ $\left.\mathrm{Hz}, J_{2}=6.6 \mathrm{~Hz}, 4 \mathrm{H}\right), 7.51\left(\mathrm{dd}, J_{1}=3.0 \mathrm{~Hz}, J_{2}=6.6 \mathrm{~Hz}, 4 \mathrm{H}\right) .{ }^{13} \mathrm{C}$ NMR $\left(400 \mathrm{MHz}, \mathrm{C}_{6} \mathrm{D}_{6}\right) \delta 159.9,126.8,125.9,125.4,119.5,118.9$, 106.4, 71.9, 70.3, 69.1, 68.1. Anal. Calcd (found) for $\mathrm{C}_{42} \mathrm{H}_{32} \mathrm{Fe}_{2} \mathrm{Ti}$. $\mathrm{H}_{2} \mathrm{O}: \mathrm{C}, 70.62$ (70.64); H, 4.80 (5.23). IR (neat) $\nu_{\mathrm{C} \equiv \mathrm{C}}=2048 \mathrm{~cm}^{-1}$.

Ind ${ }_{2} \mathrm{Ti}\left(\mathrm{C}_{2} \mathrm{Fc}\right)_{2} \mathrm{CuBr}$. To an argon-purged oven-dried two-neck round-bottom flask $(25 \mathrm{~mL})$, dry THF $(10 \mathrm{~mL}), \operatorname{Ind}_{2} \mathrm{Ti}\left(\mathrm{C}_{2} \mathrm{Fc}\right)_{2}$
(100 mg, $0.144 \mathrm{mmol})$, and $\mathrm{CuBr}(41 \mathrm{mg}, 0.287 \mathrm{mmol})$ were added. The flask was stirred at room temperature for $2 \mathrm{~h}$. The solvent was removed using rotary evaporation. The solid was then loaded onto a silica gel column $(1 \mathrm{~cm} \times 12 \mathrm{~cm})$ and eluted using a $5 \%$ mixture of triethylamine in $\mathrm{CH}_{2} \mathrm{Cl}_{2}$. The dark green band was collected and the solvent removed using rotary evaporation. The solid was dissolved in minimal $\mathrm{CH}_{2} \mathrm{Cl}_{2}(2 \mathrm{~mL})$ and precipitated with hexanes $(20 \mathrm{~mL})$. The solid was collected using vacuum filtration, washed with $\mathrm{Et}_{2} \mathrm{O}(1 \mathrm{~mL})$, and dried under vacuum, yielding $82 \mathrm{mg}(68 \%)$ of a dark green solid. UV-vis (THF) $\lambda_{\max }(\varepsilon)$; 398 (8990), 619 (3990). UV-vis $\left(\mathrm{CH}_{2} \mathrm{Cl}_{2}\right)$ $\lambda_{\max }(\varepsilon)$; 392 (10000), 621 (6180). ${ }^{1} \mathrm{H}$ NMR $\left(400 \mathrm{MHz}, \mathrm{CDCl}_{3}\right) \delta$ $4.27(\mathrm{~s}, 10 \mathrm{H}), 4.32\left(\mathrm{dd}, J_{1}=J_{2}=1.87 \mathrm{~Hz}, 4 \mathrm{H}\right), 4.64\left(\mathrm{dd}, J_{1}=J_{2}=\right.$ $1.87 \mathrm{~Hz}, 4 \mathrm{H}), 5.90(\mathrm{t}, J=3.30 \mathrm{~Hz}, 2 \mathrm{H}), 6.00(\mathrm{~d}, J=3.30 \mathrm{~Hz}, 4 \mathrm{H})$, $7.29\left(\mathrm{dd}, J_{1}=3.1 \mathrm{~Hz}, J_{2}=6.5 \mathrm{~Hz}, 4 \mathrm{H}\right), 7.52\left(\mathrm{dd}, J_{1}=3.1 \mathrm{~Hz}, J_{2}=6.5\right.$ $\mathrm{Hz}, 4 \mathrm{H}) .{ }^{13} \mathrm{C}$ NMR $\left(400 \mathrm{MHz}, \mathrm{CDCl}_{3}\right) \delta 145.5,131.6,126.8,125.9$ 123.9, 114.4, 103.3, 72.8, 70.3, 69.9, 66.1. Anal. Calcd (found) for $\mathrm{C}_{42} \mathrm{H}_{32} \mathrm{Fe}_{2} \mathrm{TiCuBr}: \mathrm{C}, 60.07$ (59.77); H, 3.84 (3.99). IR (neat) $\nu_{\mathrm{C} \equiv \mathrm{C}}$ $=1986 \mathrm{~cm}^{-1}$.

X-ray Crystallography and Crystal Structure Determination. Single crystals of $\operatorname{Ind}_{2} \mathrm{Ti}\left(\mathrm{C}_{2} \mathrm{Fc}\right)_{2} \mathrm{CuBr}$ were grown in an NMR tube by layering about $5 \mathrm{~mm}$ of acetone and then several centimeters of hexanes onto a THF solution of the compound containing a few drops of triethylamine for long-term stability. Single crystal X-ray diffraction data were collected at $173 \mathrm{~K}$ using a Bruker D8 Venture diffractometer with Mo $\mathrm{K} \alpha$ radiation from an Incoatec $\mathrm{I} \mu \mathrm{S}$ source and a Photon 100 detector. Space group determination (XPREP), structure solution (SHELXT), and structure refinement by full-matrix least-squares techniques on F2 (SHELXL) were performed using the SHELXTL software package. ${ }^{40}$ All non-hydrogen atoms were refined anisotropically. Hydrogen atoms attached to carbon atoms were placed in geometrically optimized positions using appropriate riding models. The proper absolute structure in the non-centrosymmetric space group $F d d 2$ is supported by the Flack parameter of $0.051(5)$. Further details of the refinement and crystallographic data are given in the Supporting Information and are available through the Cambridge Crystallographic Data Centre, CCDC deposition number 1968308.

\section{ASSOCIATED CONTENT}

\section{S1 Supporting Information}

The Supporting Information is available free of charge at https://pubs.acs.org/doi/10.1021/acs.organomet.9b00818.

${ }^{1} \mathrm{H}$ and ${ }^{13} \mathrm{C}$ NMR spectra for $\operatorname{Ind}_{2} \mathrm{Ti}\left(\mathrm{C}_{2} \mathrm{Fc}\right)_{2}$ and Ind $_{2} \mathrm{Ti}\left(\mathrm{C}_{2} \mathrm{Fc}\right)_{2} \mathrm{CuBr}$, crystallographic data for $\operatorname{Ind}_{2} \mathrm{Ti}-$ $\left(\mathrm{C}_{2} \mathrm{Fc}\right)_{2} \mathrm{CuBr}$ and several different orientations and packing arrangement for it structure, UV-vis spectra in THF, sweep-rate dependence of the cathodic wave for $\operatorname{Ind}_{2} \mathrm{Ti}\left(\mathrm{C}_{2} \mathrm{Fc}\right)_{2}$, effect of reversal potential on the anodic waves for $\operatorname{Ind}_{2} \mathrm{Ti}\left(\mathrm{C}_{2} \mathrm{Fc}\right)_{2}(\mathrm{PDF})$

Structure data (XYZ)

\section{Accession Codes}

CCDC 1968308 contains the supplementary crystallographic data for this paper. These data can be obtained free of charge via www.ccdc.cam.ac.uk/data_request/cif, or by emailing data_request@ccdc.cam.ac.uk, or by contacting The Cambridge Crystallographic Data Centre, 12 Union Road, Cambridge CB2 1EZ, UK; fax: +44 1223336033.

\section{AUTHOR INFORMATION}

\section{Corresponding Author}

Paul S. Wagenknecht - Department of Chemistry, Furman University, Greenville, South Carolina 29609, United States; (1) orcid.org/0000-0001-8698-073X; Email: paul.wagenknecht@furman.edu 


\section{Authors}

Khiem T. Nguyen - Department of Chemistry, Furman University, Greenville, South Carolina 29609, United States

Emily E. Lane - Department of Chemistry, Furman University, Greenville, South Carolina 29609, United States

Colin D. McMillen - Department of Chemistry, Clemson University, Clemson, South Carolina 29634, United States; - orcid.org/0000-0002-7773-8797

Jared A. Pienkos - Department of Chemistry, Furman University, Greenville, South Carolina 29609, United States

Complete contact information is available at: https://pubs.acs.org/10.1021/acs.organomet.9b00818

\section{Notes}

The authors declare no competing financial interest.

\section{ACKNOWLEDGMENTS}

This work was supported by the National Science Foundation under Grant CHE-1362516 (P.S.W.) and in part through the EPSCoR Program under NSF Award \# OIA-1655740. Any opinions, findings, and conclusions or recommendations expressed in this material are those of the authors and do not necessarily reflect those of the National Science Foundation. K.T.N. acknowledges support through the Furman Summer Fellows Program.

\section{REFERENCES}

(1) Kealy, T. J.; Pauson, P. L. A new type of organo-iron compound. Nature 1951, 168, 1039-1040.

(2) (a) Wilkinson, G.; Rosenblum, M.; Whiting, M. C.; Woodward, R. B. The structure of iron bis-cyclopentadienyl. J. Am. Chem. Soc. 1952, 74, 2125-2126. (b) Fischer, E. O.; Pfab, W. On the crystal structure of the bis-cyclopentadienyl compounds of divalent iron, cobalt and nickel. Z. Anorg. Allg. Chem. 1952, 7, 377-379.

(3) Trost, B. M.; Ryan, M. C. Indenylmetal catalysis in organic synthesis. Angew. Chem., Int. Ed. 2017, 56, 2862-2879.

(4) Hart-Davis, A. J.; Mawby, R. J. Reactions of R-lndenyl Complexes of Transition Metals. Part 1. Kinetics and Mechanisms of Reactions of Tricarbonyl- $\pi$-indenylmethylmolybdenum with Phosphorus(III) Ligands. J. Chem. Soc. A 1969, 0, 2403-2407.

(5) (a) Rerek, M. E.; Ji, L.-N.; Basolo, F. The Indenyl Ligand Effect on the Rate of Substitution Reactions of $\mathrm{Rh}\left(\eta-\mathrm{C}_{9} \mathrm{H}_{7}\right)(\mathrm{CO})_{2}$ and $\mathrm{Mn}\left(\left(\eta-\mathrm{C}_{9} \mathrm{H}_{7}\right)(\mathrm{CO})_{3}\right.$. J. Chem. Soc., Chem. Commun. 1983, 12081209. (b) O'Connor, J. M.; Casey, C. P. Ring-slippage chemistry of transition metal cyclopentadienyl and indenyl complexes. Chem. Rev. 1987, 87 (2), 307-318.

(6) Cadierno, V.; Díez, J.; Gamasa, M. P.; Gimeno, J.; Lastra, E. Indenyl complexes of Group 8 metals. Coord. Chem. Rev. 1999, 193195, 147-205.

(7) Calhorda, M. J.; Romão, C. C.; Veiros, L. F. The Nature of the Indenyl Effect. Chem. - Eur. J. 2002, 8 (4), 868-875.

(8) Crossley, N. S.; Green, J. C.; Nagy, A.; Stringer, G. Electronic structure of transition-metal indenyl compounds: a He I and He II photoelectron spectroscopic study of $\left[\mathrm{Mn}\left(\eta^{5}-\mathrm{C}_{9} \mathrm{H}_{7}\right)(\mathrm{CO})_{3}\right],\left[\mathrm{Fe}\left(\eta^{5}-\right.\right.$ $\left.\left.\mathrm{C}_{9} \mathrm{H}_{7}\right)_{2}\right],\left[\mathrm{Ru}\left(\eta^{5}-\mathrm{C}_{9} \mathrm{H}_{7}\right)_{2}\right]$, and $\left.\left[\mathrm{Ru}\left(\eta^{5}-\mathrm{C}_{9} \mathrm{H}_{7}\right) \eta-\mathrm{C}_{5} \mathrm{Me}_{5}\right)\right]$. J. Chem. Soc., Dalton Trans. 1989, No. 11, 2139-2147.

(9) Frankcom, T. M.; Green, J. C.; Nagy, A.; Kakkar, A. K.; Marder, T. B. Electronic structure and photoelectron spectroscopy of $\mathrm{d}^{8}$ rhodium indenyl complexes. Organometallics 1993, 12 (9), 36883697.

(10) Ambrosi, L.; Bassetti, M.; Buttiglieri, P.; Mannina, L.; Monti, D.; Bocelli, G. Synthesis and structure of acylcarbonylindenyl(phosphine) iron(II). J. Organomet. Chem. 1993, 455 (1-2), 167175 .

(11) Gamasa, M. P.; Gimeno, J.; González-Bernardo, C.; MartínVaca, B. M.; Monti, D.; Bassetti, M. Phosphine Substitution in
Indenyl- and Cyclopentadienylruthenium Complexes. Effect of the $\eta^{5}$ Ligand in a Dissociative Pathway. Organometallics 1996, 15 (1), 302308.

(12) Pauson, P. L.; Wilkinson, G. Bis-indenyl Derivatives of Iron and Cobalt. J. Am. Chem. Soc. 1954, 76 (7), 2024-2026.

(13) Samuel, E.; Hénique, J. Phosphine complexes of Ti(III) and $\mathrm{Zr}(\mathrm{III})$ : detection in solution by EPR/electrochemical methods. $J$. Organomet. Chem. 1996, 512 (1-2), 183-187.

(14) Miller, G. A.; Therien, M. J.; Trogler, W. C. Electrochemical studies of an oxidatively induced ring slippage in 17-electron $\left(\eta^{3}\right.$ indenyl $)\left(\eta^{5}\right.$-indenyl $) \mathrm{V}(\mathrm{CO})_{2}$. J. Organomet. Chem. 1990, $383(1-3)$, 271-278.

(15) Turlington, M. D.; Pienkos, J. A.; Carlton, E. S.; Wroblewski, K. N.; Myers, A. R.; Trindle, C. O.; Altun, Z.; Rack, J. J.; Wagenknecht, P. S. Complexes with Tunable Intramolecular Ferrocene to $\mathrm{Ti}^{\mathrm{IV}}$ Electronic Transitions: Models for Solid State $\mathrm{Fe}^{\mathrm{II}}$ to $\mathrm{Ti}^{\mathrm{IV}}$ Charge Transfer. Inorg. Chem. 2016, 55, 2200-2211.

(16) Pienkos, J. A.; Webster, A. B.; Piechota, E. J.; Agakidou, A. D.; McMillen, C. D.; Pritchett, D. Y.; Meyer, G. J.; Wagenknecht, P. S. Oxidatively stable ferrocenyl- $\pi$-bridge-titanocene D- $\pi$-A complexes: an electrochemical and spectroscopic investigation of the mixedvalent states. Dalton Trans. 2018, 47, 10953-10964.

(17) Livshits, M. Y.; Turlington, M. D.; Trindle, C. O.; Wang, L.; Altun, Z.; Wagenknecht, P. S.; Rack, J. J. Picosecond to Nanosecond Manipulation of Excited-State Lifetimes in Complexes with an $\mathrm{Fe}^{\mathrm{II}}$ to $\mathrm{Ti}^{\mathrm{IV}}$ Metal-to-Metal ChargeTransfer: The Role of Ferrocene-Centered Excited States. Inorg. Chem. 2019, 58, 15320-15329.

(18) Back, S.; Rheinwald, G.; Lang, H. Synthesis, electrochemistry and electronic spectra of tetranuclear bis $\left(\eta^{2}\right.$-alkynyl $)$ transition-metal complexes. The molecular structure of $\left[\left(\eta^{5}-\mathrm{C}_{5} \mathrm{H}_{4} \mathrm{SiMe}_{3}\right)_{2} \mathrm{Ti}-\right.$ $\left.(\mathrm{CCF})_{2}\right] \mathrm{CuBr}$. J. Organomet. Chem. 2000, 601, 93-99.

(19) Back, S.; Stein, T.; Frosch, W.; Wu, I.-Y.; Kralik, J.; Büchner, M.; Huttner, G.; Rheinwald, G.; Lang, H. Heterometallic early-late Htweezer complexes: their synthesis, electrochemical behaviour, and the solid state structures of $\left(\eta^{5}-\mathrm{C}_{5} \mathrm{H}_{4} \mathrm{SiMe}_{3}\right)_{2} \mathrm{Ti}(\mathrm{CCPh})_{2}$ and $\left[\left(\eta^{5}-\right.\right.$ $\left.\left.\mathrm{C}_{5} \mathrm{H}_{4} \mathrm{SiMe}_{3}\right)_{2} \mathrm{Ti}(\mathrm{CCPh})_{2}\right] \mathrm{Pd}\left(\mathrm{PPh}_{3}\right)$. Inorg. Chim. Acta 2001, 325, 94-102.

(20) Vieira, N. C.; Pienkos, J. A.; McMillen, C. D.; Myers, A. R.; Clay, A. P.; Wagenknecht, P. S. A trans-bidentate bis-pyridinyl ligand with a transition metal hinge. Dalton Trans. 2017, 46, 15195-15199.

(21) Faller, J. W.; Crabtree, R. H.; Habib, A. Control of Slippage and Conformation in Indenyl Complexes. Organometallics 1985, 4, 929935.

(22) Westcott, S. A.; Kakkar, A. K.; Stringer, G.; Taylor, N. J.; Marder, T. B. Flexible coordination of indenyl ligands in sandwich complexes of transition metals. Molecular structures of $\left[\left(\eta-\mathrm{C}_{9} \mathrm{R}_{7}\right)_{2} \mathrm{M}\right]$ $(\mathrm{M}=\mathrm{Fe}, \mathrm{R}=\mathrm{H}, \mathrm{Me} ; \mathrm{M}=\mathrm{Co}, \mathrm{Ni}, \mathrm{R}=\mathrm{H})$ : Direct measurement of the degree of slip-fold distortion as a function of d-electron count. J. Organomet. Chem. 1990, 394, 777-794.

(23) Back, S.; Pritzkow, H.; Lang, H. C ${ }_{2}$-Bridged TitanoceneFerrocenyl Compleses: Synthesis, Reaction Chemistry, and Electrochemical Behavior. Organometallics 1998, 17, 41-44.

(24) Hayashi, Y.; Osawa, M.; Wakatsuki, Y. Reductive coupling reaction induced by remote-site oxidation in titaocene bis(metallocenylacetylide), where metallocenyl = ferrocenyl or ruthenocenyl: a novel route to $C_{n}(n=4,6$, and 8) wire with the metallocenyl groups at both terminals. J. Organomet. Chem. 1997, 542, 241-246.

(25) Barrière, F.; Camire, N.; Geiger, W. E.; Mueller-Westerhoff, U. T.; Sanders, R. Use of Medium Effects to Tune the $\mathrm{UE}_{1 / 2}$ Values of Bimetallic and Oligometallic Compounds. J. Am. Chem. Soc. 2002, $124,7262-7263$.

(26) Diallo, A. K.; Absalon, C.; Ruiz, J.; Astruc, D. FerrocenylTerminated Redox Stars: Synthesis and Electrostatic Effects in MixedValence Stabilization. J. Am. Chem. Soc. 2011, 133, 629-641.

(27) Treichel, P. M.; Johnson, J. W.; Wagner, K. P. Electrochemical oxidations of various indenyl-iron complexes. J. Organomet. Chem. 1975, 88 (2), 227-230. 
(28) Hill, M. G.; Lamanna, W. M.; Mann, K. R. Tetrabutylammonium tetrakis[3,5-bis(trifluoromethyl)phenyl]borate as a noncoordinating electrolyte: Reversible 1e- oxidations of ruthenocene, osmocene, and $\mathrm{Rh}_{2}(\mathrm{TM} 4)_{4}{ }^{2+}$ (TM4 = 2,5-diisocyano-2,5-dimethylhexane). Inorg. Chem. 1991, 30, 4687-4690.

(29) Kukharenko, S. V.; Strelets, V. V.; Kudinov, A. R.; Kreidlin, A. Z.; Peterleitner, M. G.; Denisovich, L. I.; Rybinskaya, M. I. Reactivity of 17- and 19-electron organometallic complexes. Formation of bent sandwich 19-electron radical cation complexes of osmium and ruthenium. J. Organomet. Chem. 1996, 519 (1-2), 1-5.

(30) Geiger, W. E. Electroreduction of Cobaltocene. Evidence for a Metallocene Anion. J. Am. Chem. Soc. 1974, 96, 2632-2634.

(31) Knizhnikov, V. A.; Shirokii, V. L.; Dikusar, E. A.; Ryabtsev, A. N.; Maier, N. A. Derivatives of bis $\left(\eta^{5}\right.$-indenyl)cobalt. Russ. J. Gen. Chem. 1997, 67 (10), 1634-1637.

(32) Weiß, T.; Natarajan, K.; Lang, H.; Holze, R. Indenyl-titaniumtrichloride complexes: correlations between electrochemical and UVvis-spectroscopic data. J. Electroanal. Chem. 2002, 533 (1-2), 127133.

(33) Kowaleski, R. M.; Rheingold, A. L.; Trogler, W. C.; Basolo, F. Synthesis and Structure of Dicarbonyl $\left(\eta^{3}\right.$-indenyl $)\left(\eta^{5}\right.$-indenyl)vanadium(II). An Unusual Slipped Ring in a Metal Radical. J. Am. Chem. Soc. 1986, 108, 2460-2461.

(34) Gamelas, C. A.; Herdtweck, E.; Lopes, J.; Romao, C. C. RedoxInduced Indenyl Slippage in $[\mathrm{IndCpMoL}]^{2+/+/ 0}$ Complexes. Organometallics 1999, 18, 506-515.

(35) Lee, S.; Lovelace, S. R.; Cooper, N. J. Two-Electron and OneElectron Reduction of the Indenyl Complex $\left[\mathrm{Mn}\left(\eta^{5}-\mathrm{C}_{9} \mathrm{H}_{7}\right)(\mathrm{CO})_{3}\right]$ and Reversible Counterion-Controlled Comproportionation of [Mn$\left.\left(\eta^{5}-\mathrm{C}_{9} \mathrm{H}_{7}\right)(\mathrm{CO})_{3}\right]$ and $\left[\mathrm{Mn}\left(\eta^{3}-\mathrm{C}_{9} \mathrm{H}_{7}\right)(\mathrm{CO})_{3}\right]^{2-}$ To Give $\left[\mathrm{Mn}\left(\eta^{5}-\right.\right.$ $\left.\left.\mathrm{C}_{9} \mathrm{H}_{7}\right)(\mathrm{CO})_{3}\right]^{-}$. Organometallics 1995, 14, 1974-1982.

(36) (a) Allen, G. C.; Hush, N. S. Intervalence-Transfer Absorption. Part 1. Qualitative Evidence for Intervalence-Transfer Absorption in Inorganic Systems in Solution and in the Solid State. Prog. Inorg. Chem. 2007, 8, 357-444. (b) Creutz, C. Mixed Valence Complexes of $d^{5}-d^{6}$ Metal Centers. Prog. Inorg. Chem. 1983, 30, 1-73. (c) Katz, N. E.; Creutz, C.; Sutin, N. 4-Cyanopyridine-bridged binuclear and trinuclear complexes of ruthenium and iron. Inorg. Chem. 1988, 27, 1687-1694. (d) Bernhardt, P. V.; Macpherson, B. P.; Martinez, M. The influence of cis/trans isomerism on the physical properties of a cyano-bridged dinuclear mixed valence complex. J. Chem. Soc., Dalton Trans. 2002, 1435-1441.

(37) Ratera, I.; Sporer, C.; Ruiz-Molina, D.; Ventosa, N.; Baggerman, J.; Brouwer, A. M.; Rovira, C.; Veciana, J. Solvent Tuning from Normal to Inverted Marcus Region of Intramolecular Electron Transfer in Ferrocene-Based Organic Radicals. J. Am. Chem. Soc. 2007, 129, 6117-6129.

(38) Brunschwig, B. S.; Ehrenson, S.; Sutin, N. Solvent Reorganization in Optical and Thermal Electron-Transfer Processes. J. Phys. Chem. 1986, 90, 3657-3668.

(39) LeSuer, R. J.; Buttolph, C.; Geiger, W. E. Comparison of the Conductivity Properties of the Tetrabutylammonium Salt of Tetrakis(pentafluorophenyl)borate Anion with Those of Traditional Supporting Electrolyte Anions in Nonaqueous Solvents. Anal. Chem. 2004, 76, 6395-6401.

(40) Sheldrick, G. M. Crystal Structure Refinement with SHELXL. Acta Crystallogr., Sect. C: Struct. Chem. 2015, 71, 3-8. 